\title{
Stadsgroen onder spanning
}

\author{
Debatten over ruimtegebruik in negentiende-eeuws Antwerpen
}

Andreas Stynen \& Bart Tritsmans

TVGESCH 128 (1): 45-68

DOI: 10.5117/TVGESCH2015.1.STYN

\begin{abstract}
Urban nature under tension. Dissension over a new policy domain in nineteenth-century Antwerp Research on urban green space is usually limited to those types of greenery with an official character. Unofficial green spaces, such as fallows between buildings or near ramparts, are harder to study, as are the varied uses of (un)official green spaces. This article analyses the multi-layered negotiations among politicians, citizens, civil servants, specialists, and even the press in the greening of nineteenth-century Antwerp. A series of debates fuelled the need for a special administration for this new sphere of the public domain. Moreover, regulations were issued in order to enforce proper behaviour. Testimonials suggest how common people actually experienced their surroundings, revealing many official attempts as naive. While the authorities tried to extend their power, the expectations about urban nature also shifted: a strictly utilitarian perspective was followed by a rather aesthetic view, which in turn was challenged by concerns of both an ecological and recreational nature.
\end{abstract}

Keywords: urban history, nineteenth century, urban green space, wastelands, city dwellers

Zowel in de hedendaagse maatschappij als in recent historisch onderzoek is er een erg grote belangstelling voor stedelijke groenruimtes. ${ }^{1}$ Tot nog toe richtten wetenschappelijke studies zich vooral op de bekendste groentypes zoals parken,

1 Zie voor recent historisch onderzoek naar stedelijk groen: A. Stynen en B. Tritsmans, 'Het groene verleden van de industriële stad. Wortels en bloei van het historisch onderzoek naar de stedelijke groenruimte in de negentiende en twintigste eeuw', Stadsgeschiedenis 7.1 (2012) 96-112. straatbomen en tuinwijken, hoewel al herhaaldelijk werd aangegeven dat ook minder voor de hand liggende vormen van groen aan bod moeten komen. ${ }^{2}$ De eenzijdige focus op officiële bronnen heeft gezorgd voor een vertroebeling van de gelaagdheid van de stedelijke groenruimte.

2 P. Clark en J. Jauhiainen, 'Introduction', in P. Clark ed., The European city and the green space. London, Stockholm, Helsinki and St Petersburg, 1850-2000 (Aldershot 2006) 6 . 


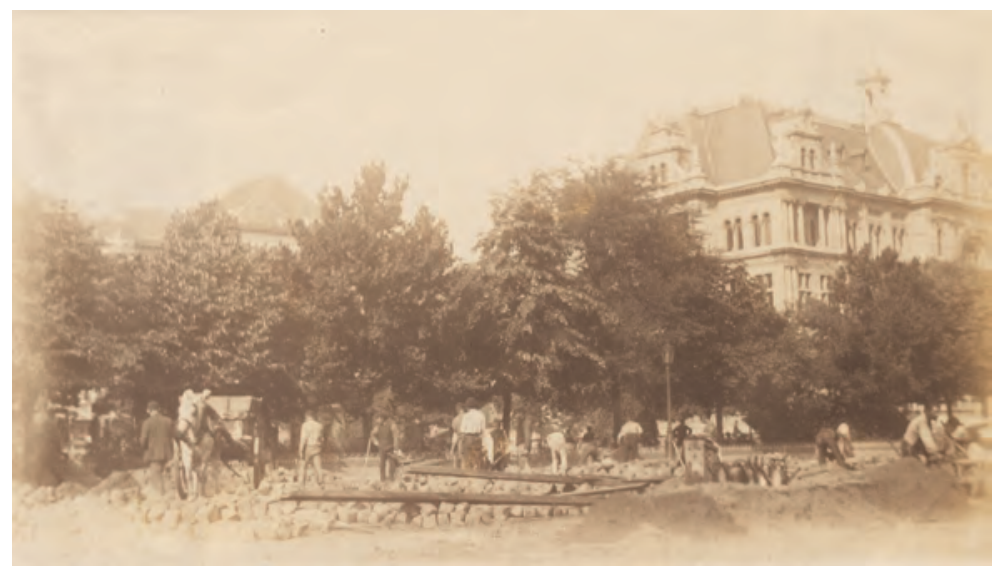

De Gemeenteplaats, in de volksmond de Geuzenhofkens (naar het liberale stadsbestuur), wordt heraangelegd. Werklieden leggen kasseien tussen de bomen. Achter de bomen het gloednieuwe Koninklijk Atheneum, 1885

De beleving van de stedelijke (groen-) ruimte en het belang van officieuze groenzones bleven onderbelicht en werden tot nu toe steeds benaderd vanuit officiële reglementen, romans en reisverhalen. ${ }^{3}$ In dit artikel overstijgen we het beleidsperspectief en schetsen we een alternatief beeld dat tot een nuancering van eerdere studies leidt. We schetsen de fricties en onderhandelingsprocessen die de Antwerpse groenruimte tijdens de lange negentiende eeuw bepaalden, en concentreren ons niet enkel op officiële groenzones, maar ook op minder geanalyseerde vormen van groen. ${ }^{4}$ Om de evolutie en de betekenis van stedelijk groen in relatie met de geschiedenis van een stad te bestuderen is het van kapitaal belang om

3 Recent verscheen een erg interessante studie over de beleving en de verbeelding van de stedelijke ruimte: I. Bertels e.a. ed., Tussen beleving en verbeelding. De stad in de negentiende-eeuwse literatuur (Leuven 2013).

4 A. Stynen, Proeftuinen van burgerlijkheid. Stadsnatuur in negentiende-eeuws Belgie (onuitgegeven doctoraatsverhandeling KU Leuven 2010); B. Tritsmans, Waardevolle bijkomstigheden. Stedelijk groen in beleid en beleving, Antwerpen 1859-1973 (onuitgegeven doctoraatsverhandeling Universiteit Antwerpen 2014). door te dringen tot de beleving van de bewoners. De perceptie van de gebruiker werpt immers een heel ander licht op de geschiedenis van de stedelijke (groen-) ruimte. Antwerpen werd gekozen als casestudy omdat de stad aan het einde van de negentiende eeuw de reputatie had van Europese stad met het minste publiek groen, wat leidde tot politiek en sociaal getouwtrek over de stedelijke ruimte.

In een studie over Londense groenruimtes merkte David Reeder op dat de historiografie over Britse parken te sterk bepaald werd door officiële discoursen. ${ }^{5}$ Volgens Reeder werden de streng gereguleerde parken ingepast in de disciplineringsgolf tijdens de Victoriaanse periode. Ook andere auteurs stelden impliciet of expliciet dat de parkregels en de wijze van aanleg het gedrag van de bezoekers bepaalden. Parkbezoekers - die doorgaans een andere visie hadden op parkgebruik dan de stedelijke overheden - tastten echter voortdurend hun grenzen af.

5 D. Reeder, 'The social construction of green space in London prior to the Second World War,' in: Clark ed., The European city, 51-52. 
Patrick Joyce meende dat parken over heterotopic qualities beschikten; ${ }^{6}$ Chandra Mukerji toonde aan dat groenzones vaak veel complexere machtsverhoudingen weerspiegelden dan de strikte regels en disciplineringspogingen deden vermoeden. ${ }^{7}$

In recent onderzoek naar de waarde van stedelijk groen in de hedendaagse stad vindt het gebruikersperspectief steeds meer aanhang. Ook in hedendaags landschapsonderzoek is er interesse in de beleving van stedelijk groen door verschillende doelgroepen in de stad. Aangezien kindvriendelijkheid een belangrijk thema is in de eenentwintigste-eeuwse stad, krijgt de beleving van de stedelijke ruimte door stadskinderen veel aandacht. Historisch onderzoek naar stedelijk groen vanuit het perspectief van de gebruikers is van recente aard, maar krijgt internationaal steeds meer aandacht. Een pioniersstudie die deze spanning centraal stelde is Nan Drehers artikel 'The virtuous and the verminous', over controversieel gedrag in stedelijke parken in Londen. ${ }^{8}$ Dreher focuste op twee specifieke vormen van wangedrag die tot morele paniek leidden aan het einde van de negentiende eeuw: 'public displays of affection by "courting couples" and the presence of "verminous persons" (mostly vagrants)'. ${ }^{9}$ Hoewel Drehers onderzoek voornamelijk gebaseerd is op

6 P. Joyce, The rule of freedom. Liberalism and the modern city (Londen 2003) 219-224. Joyce baseerde zich op Foucaults concept heterotopia: M. Foucault, 'Of other spaces, heterotopias', Architecture, Mouvement, Continuité 5 (1984) 46-49.

7 C. Mukerji, 'The political mobilization of nature in seventeenth-century French formal gardens', Theory and Society 23.5 (1994) 651-677.

8 N. H. Dreher, 'The virtuous and the verminous. Turn-of-the-century moral panics in London's public parks', Albion 29.2 (1997) 246-267.

9 Ibidem, 246. officiële bronnen, zoals verslagen van de Commons and Open Spaces Committee, slaagde ze er toch in om een inkijk te bieden in het dagelijkse parkgebruik aan het einde van de negentiende eeuw. Regelmatig lapten stadsbewoners de strikte reglementen en de opmerkingen van de bewakers aan hun laars, wat Dreher deed besluiten dat parkgebruikers een loopje namen met de officiële regels. ${ }^{10}$

Margo De Koster en Herbert Reinke toonden aan dat pogingen om de stad te ordenen en om de bevolking gedragscodes op te leggen onophoudelijk werden gecontesteerd door stadsbewoners die zich de stedelijke ruimte op een andere manier toe-eigenden. ${ }^{11}$ De 'overtreders' waren met hun ongewenst gedrag doorgaans op zoek naar persoonlijke betekenisgeving en expressie, maar door de afwijkende opvatting over normaliteit en conventioneel gedrag lokten ze regelmatig reactie uit bij het stadsbestuur of de politie. ${ }^{2}$ De Koster en Reinke gaven aan dat zulke transgressies enerzijds een gevoel van vrijheid en plezier konden teweegbrengen, maar dat ze anderzijds geinterpreteerd konden worden als uitingen van angst en frustratie over sociale uitsluiting. ${ }^{13}$

Simo Laakkonen benaderde de dage-

10 Ibidem, 251.

11 M. De Koster en H. Reinke, 'Tagungsbericht über eine internationale und interdisziplinäre Veranstaltungsserie. Variationen und Dimensionen der Aneignung von Stadt, USA/Europa', Informationen zur modernen Geschichte 2 (2010) 132-138.

12 M. De Koster en H. Reinke, 'Geheimen van jongeren. De Antwerpse jeugd en haar nachtleven in de vroege twintigste eeuw', Tijdschrift over Cultuur \& Criminaliteit 2.2 (2012) 32-46, aldaar 33 .

13 Ibidem, 33 . 


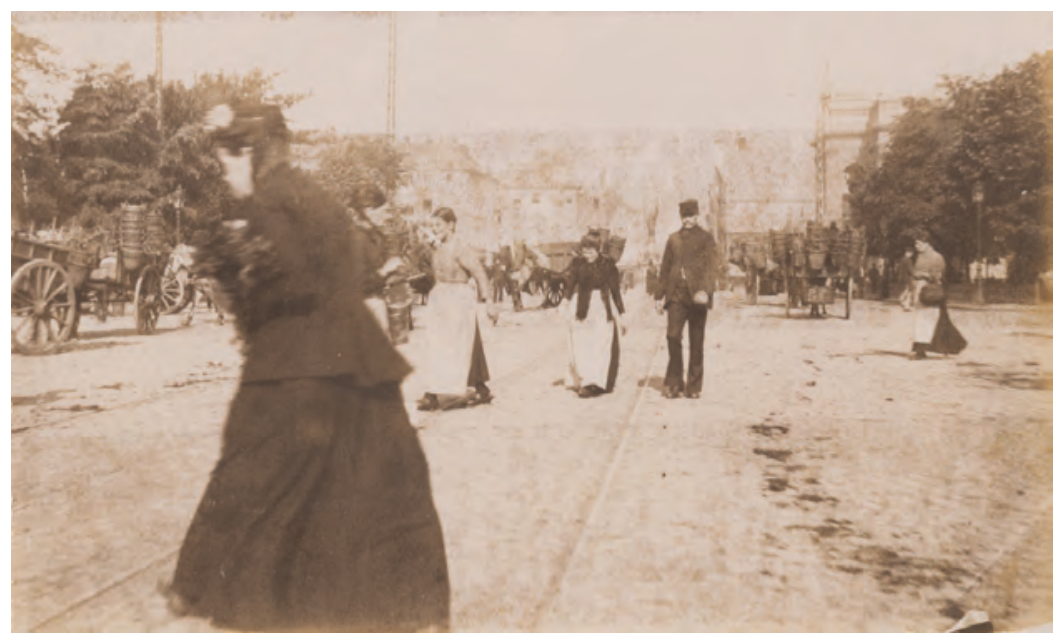

Een dame en enkele dienstmeisjes wandelen over de Gemeenteplaats, 1884-1894

Stadsarchief Antwerpen

lijkse beleving van kinderen in de stad als eerste vanuit een historisch perspectief. ${ }^{14}$ Laakkonen bestudeerde hoe kinderen hun directe omgeving beleefden in het verleden en hoe ze de omgeving aanpasten aan hun eigen noden. ${ }^{15}$ De conclusies van het onderzoek belichtten een aspect dat ook in de beleving van stedelijke groenruimtes van groot belang is: de behoefte van kinderen aan veilige, liefdevolle omgevingen aan de ene kant, en aan spannende, beangstigende ruimtes aan de andere kant. ${ }^{16}$ De auteur gaf aan dat de bronnen voor onderzoek naar de beleving van kinderen erg schaars zijn. Zijn studie is grotendeels gebaseerd op officiële bronnen, maar als voorsmaakje op de mogelijkheden van het belevingsonderzoek zette hij een kleinschalig experiment op met mondelinge geschiedenis. ${ }^{17}$ Laakkonen geeft de valkuilen van het belevingsonderzoek erg helder weer: 'de herinneringen van mensen kun-

14 S. Laakkonen, 'Asphalt kids and the matrix city. Reminiscences of children's urban environmental history', Urban History 38.2 (2011) 301-323.

15 Ibidem, 303.

16 Ibidem, 322.

17 Ibidem, 304 . nen beïnvloed zijn door mythes over een bepaalde periode, of door de herinnering van anderen. De wereld van de kindertijd heeft misschien zelfs nooit echt bestaan, behalve in iemands persoonlijke herinnering. Het verzamelen van herinneringen en er conclusies uit trekken, is zoals het maken van puzzel: met elk stukje wordt het beeld vollediger, en hoe meer materiaal er voorhanden is, hoe representatiever het resultaat. ${ }^{, 18}$ De link tussen jeugd, steden en de publieke ruimte vormde recent het onderwerp van onderzoek. ${ }^{19}$ De meeste studies zijn echter gericht op de houding van het stadsbestuur ten opzichte van kinderen omdat het erg moeilijk is om de perceptie van kinderen te reconstrueren. ${ }^{20}$

18 Ibidem, 304-305.

19 A. Schildt en D. Siegfried ed., European cities, youth and the public sphere in the twentieth century (Aldershot 2005).

20 I. Mayer, 'Children and the quest for purity in the nineteenth century Scottish city', Paedagogica Historica 33.3 (2009) 801-824. 


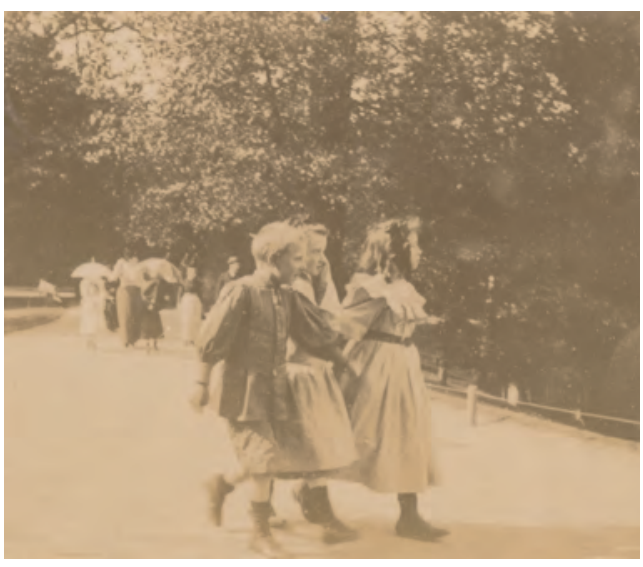

Wandelende kinderen in het stadspark, 1895

Stadsarchief Antwerpen

Ons onderzoek legt de nadruk op de individuele beleving van de stadsbewoners. Met dit artikel willen we een bijdrage leveren aan de historiografie door enerzijds een inzicht te bieden in de spanningen en de onderhandelingsprocessen tussen de verschillende actoren en groepen over het gebruik en de beleving van de stedelijke groenruimte. De officiële functie van groen beperkte zich immers vaak tot het decoreren van de stad, terwijl de gebruikers de groenruimtes in groeiende mate zagen als recreatieplaatsen. Anderzijds beschouwen we stedelijk groen in de breedste zin, wat de veellagigheid van de ruimte zal benadrukken en het belang van officieuze groenzones zal aantonen. In de eerste paragraaf wordt de ontwikkeling van stadsgroen als nieuw beleidsthema in de stedelijke besluitvorming geschetst, terwijl in de andere drie paragrafen steeds de spanning tussen het beleid en de beleving van stedelijk groen centraal zal staan.

\section{Onmacht en utopie: voorzichtige kennismakingen met stadsgroen}

Vooral dankzij de geringere oppervlakte van pre-industriële steden hadden stedelingen redelijk makkelijk toegang tot groen: buiten de omwallingen bevond men zich al snel in het ommeland, waar landbouw of zelfs ongeëxploiteerde natuur het landschap vormgaven. Die beschikbaarheid had gevolgen voor de beleving van groen. Niet dat natuurgenot ongekend was: al in de zeventiende eeuw werd gewandeld in de Franse geometrische tuinen maar ook rond de steden van de Lage Landen. Met de Plantage, vooral als grondspeculatie begonnen, kreeg Amsterdam zelfs een groen recreatiegebied waar mensen de dichtbevolkte binnenstad konden ontvluchten om te tuinieren en te kuieren. De praktijk van de promenade was in oorsprong echter hoofdzakelijk een sociaal ritueel en in tweede instantie ook een medische oefening. ${ }^{21}$ Buiten de wandelingen in de hiertoe voorziene dreven was het verband tussen natuur en vermaak zwak: de waarde van bomen lag in hun economisch rendement. Fruit en hout vormden de voornaamste aansporing om bomen te planten en ze, wars van enige sentimentaliteit, op het gepaste moment te kappen. Associaties met schoonheid lagen niet voor de hand: zo betekende de bouw van een woning vaak het einde van bomen langs de straatkant. Met esthetiek of architectuur had de natuur geen uitstaans; bomen getuigden van een

21 W. Jansen, 'Verfrissing van lichaam en geest. Aspecten van de wandeling in de $17 \mathrm{e}$ en $18 \mathrm{e}$ eeuw', Holland 28.11 (1996) 34; L. Turcot, Le promeneur à Paris au XVIIIe siècle (Parijs 2007) 95-99 en 110-111 en J.E. Abrahamse, De grote uitleg van Amsterdam. Stadsontwikkeling in de zeventiende eeuw (Bussum 2010) 211-213. 
primair utilitarisme dat in een stedelijke omgeving geen plaats kon hebben. ${ }^{22}$

In menige stad kwam de eerste georganiseerde binnenstedelijke groenvoorziening louter tot stand uit pragmatische overwegingen, meer bepaald de aanleg van een militaire verdedigingsgordel. De Spaanse omwalling die tegen 1555 rond Antwerpen was aangelegd, werd al omstreeks 1580 met bomen beplant. De wortels versterkten de wallen, terwijl de stammen zowel obstakels vormden bij een bestorming als houtvoorziening waarborgden in geval van een langdurig beleg. ${ }^{23}$ Zodra de praktijk van wandelen opgang maakte, trokken de stedelingen met plezier naar deze zone. Een prioriteit was dit gebruik echter niet: voor de autoriteiten waren de bomen bovenal een bron van inkomsten. In de Franse periode verdwenen op sommige delen van de Antwerpse omwallingen zelfs alle bomen. Sommige dienden voor de verwarming van de troepen, andere werden verkocht aan particulieren - bij gebrek aan toezicht werden ze anders toch illegaal gekapt. ${ }^{24}$ De situatie is niet geheel verschillend van Amsterdam, waar in de zeventiende eeuw bomen langs grachten een evidentie waren geworden. Hoewel observatoren vooral de esthetische dimensie noteerden, beoogden de aanplantingen bovenal praktische toepassingen, zoals de stabilisering van de kades, het regelen van de waterhuishouding, be-

22 Onder meer Brussel, Stadsarchief [=ASB], TP 44033: De la Tour aan College, 30 maart 1824; J. Delestrée aan College, 17 november 1826 en College aan gouverneur Zuid-Brabant, 23 augustus 1828.

23 H.W. Lawrence, City trees. A historical geography from the Renaissance through the nineteenth century (Charlottesville en Londen 2006) 16-26.

24 Antwerpen, Stadsarchief [= SAA], MA \#950: A. de Broux-Prest aan 'agent national' D'Argonne, 17 Prairial III en rapport door Cools en De Bourse, 3 Frimaire IV. schutting tegen de zon en koelte voor verse marktwaren. Een combinatie van decoratieve en functionele overwegingen brak in de achttiende eeuw ook in andere Nederlandse steden door, maar bleef in het Zuiden uit. ${ }^{25}$

Ondanks de utilitaristische accenten tekende zich juist in de Franse periode een kentering af in de omgang met stedelijk groen. De nieuwe machthebbers waren beducht voor kortzichtige hebzucht. Er circuleerden gedetailleerde richtlijnen over hoe het leger versterkingswerken met jonge bomen kon beplanten en particulieren kregen aanmoedigingen om daders van illegale houtkap aan te geven. ${ }^{26}$ Uiteraard waren dit functionele maatregelen om het utilitarisme ook op termijn vol te houden, maar voor het eerst was er in de zuidelijke Nederlanden tevens een doelgerichte stimulans voor groen als decoratief stadselement. Een ministeriële omzendbrief uit 1795 spoorde lokale autoriteiten aan om hun stad zoveel mogelijk op te smukken zodat de bewoners zich sterker zouden hechten. Tegelijkertijd speelde eigenbelang mee: een imponerende publieke ruimte was een façade van macht en welvaart die op bestuurders afstraalde, een strategie die ook Nederlandse bestuurders in de achttiende eeuw gretig volgden. ${ }^{27}$ Aanplantingen bleken in menige stad het antwoord op de Franse omzendbrief, een keuze die hoog-

25 Abrahamse, De grote uitleg, 289-293 en G. Medema, Achter de façade van de Hollandse stad. Het stedelijk bouwbedrijf in de achttiende eeuw (Nijmegen 2011) 190-193.

26 Programma der aenmoedigingen, toegestaen aen de borgers die Plantagien zullen forméeren (Parijs, 22 Fructidor V).

27 ASB, TP 3836: rapport van Baraumont aan burgemeester, 16 Prairial X en Medema, Achter de façade, 291. 
uit onrechtstreeks met de Romantiek te maken had: romantici zochten hun esthetische ervaringen buiten de stad, die ze als banaal en daarom bedreigend afwezen. ${ }^{28}$

Ook in Antwerpen werd op zeker twee locaties utilitarisme aan een groene esthetiek - of embellissement - verbonden. Een eerste dossier was dat van de Groenplaats. Kort na de machtsovername drong de prefect erop aan om het in onbruik geraakte kerkhof ten zuiden van de kathedraal tot een 'belle place plantée d'arbres' om te vormen. De lokale overheid verklaarde zich akkoord en de muren en graven maakten plaats voor drie rijen lindenbomen. Anders dan in het verleden was deze groenvoorziening niet exclusief ter vermaak van de elite en vreemde bezoekers, maar vormde zij een essentieel stadselement voor de eigen bevolking - een onomkeerbare democratisering. ${ }^{29}$ Diezelfde verlichte zienswijze bezielde de plannen die de (Franse) stadsbouwmeester François Verly tussen 1801 en 1803 uitwerkte. Hij wilde Antwerpen in classicistische geest heraanleggen, omgeven door met bomen afgezette lanen. ${ }^{30}$ Dit model kende hij van Parijs, waar de oude militaire omwalling plaats had gemaakt voor een brede laan geflankeerd door smallere zijlanen. Bomen zorgden voor de ruimtelijke scheiding tussen verschillende weggebruikers. Flaneren was nu in alle veiligheid

28 B. Keunen, De verbeelding van de grootstad. Stadsen wereldbeelden in het proza van de moderniteit (Brussel 2000) 30-32 en 79.

29 SAA, MA \#950: nota van Dargonne aan Bourceret, V; Dargonne aan stadsbestuur, 26 Floréal V; PV kanton Antwerpen, 27 Floréal V; redevoering door prefect van de Twee Netes, 3 Prairial XIII.

30 P. Lombaerde, 'Antwerpen 1750-1850: de moeizame metamorfose van een verwaarloosde stad', in: E. Taverne en I. Visser ed., Stedebouw. De geschiedenis van de stad in de Nederlanden van 1500 tot heden (Nijmegen 1993) 164-166. mogelijk op de grens van stad en platteland. Deze hybride ruimte vond een stimulans in de burgerlijke verbeeldingswereld, die de drang voedde om ook in de stad idyllisch gevormde natuur te 'consumeren'. ${ }^{31}$ In de nieuwe gedaante van boulevard beukte de promenade zo op de poorten van de agglomeratie, al bleven die in Antwerpen vooralsnog gesloten: op regeringsniveau werd beslist de militaire infrastructuur verder uit te bouwen. ${ }^{32}$

Het uitblijven van een boulevard fnuikte geenszins de ambities. Het vroegere galgenveld, sinds 1756 een boomkwekerij, leende zich volgens burgemeester Jean Werbrouck uitstekend voor een promenade publique. De gemeenteraad achtte de plannen in 1802 echter financieel onhaalbaar. Onderhandelingen met de nieuwe prefect wierpen zeven jaar later meer vruchten af: als de logistieke functie van de pépinière behouden bleef, mocht de stad het publiek in de Warande toelaten. ${ }^{33}$ Recreatie in het groen was een valabele optie geworden, zij het in passieve vorm: natuur was een visuele troef, geen kader voor sport en spel. Met de Warande had Antwerpen alleszins een eerste proeve van openbaar park, zij het met een bescheiden succes. De ligging net bui-

31 Zie voor Parijs de pioniersstudie van N. Green, The spectacle of nature. Landscape and bourgeois culture in nineteenth-century France (Manchester en New York 1992).

32 Verly tekende later op verzoek van koning Willem gelijkaardige plannen voor Brussel uit. De boulevard werd na een wedstrijd echter aan andere architecten toegewezen. Zie voor de evolutie van promenade naar boulevard en stadspark A. Stynen, 'Natuurlijke verbeelding. Ontkieming van het stadsparkideaal', De Negentiende Eeuw 36.1 (2012) 63-70.

33 SAA, MA \#951: notulen gemeenteraad, 17 Brumaire XI; PV Raad, 4 april 1810; Werbrouck aan D'Argenson, 30 april 1812 en D'Argenson aan minister Binnenlandse Zaken, 24 juni 1812. 
ten de stad speelde in het nadeel en beperkt toezicht leidde al snel tot een twijfelachtige reputatie. ${ }^{34}$

De Warande dwong het Antwerpse stadsbestuur tot een nieuwe bestuurlijke structuur. Spilfiguur was tuinman Pierre Maillard, de opzichter van de oude boomkwekerij. Als eerste directeur van de Warande kreeg hij jaarlijks een bescheiden budget en gedurende enkele maanden twee werklieden ter beschikking. Zijn autonomie werd beperkt door een gemeenteraadscommissie met wie voortdurend overleg nodig was. ${ }^{35}$ Maillards opvolger legde vanaf 1824 meer voluntarisme aan de dag en bedong dat hij ook esthetisch advies mocht uitbrengen, andere locaties in de stad inbegrepen. Bij gebrek aan middelen slaagde de jardinier de ville er evenwel niet in om vat te krijgen op de beschadigingen en bandeloosheid in de Warande - zeker soldaten kwamen er vaak met 'ontuchtige vrouwpersoonen'. Deze frustratie mondde wegens 'des mesures rigoureuses' tegen een vrouw die haar koeien in de boomkwekerij liet grazen zelfs uit in een strafrechtelijke veroordeling. ${ }^{36}$

Kort na de Belgische onafhankelijkheid kondigde zich in Antwerpen een nieuwe wind in het groenbeleid aan: de gemeenteraadscommissie voor de Warande hield in 1833 een fors pleidooi voor meer middelen én toezicht. Opvallend was de stelling dat voor straatbomen soorten met een mooi voorkomen moesten worden geselecteerd, zonder te overdrijven: eenmaal

34 Ruim een eeuw later werd de Warande herdoopt tot Koning Albertpark.

35 SAA, MA \#13/3: PV Raad, 4 april 1810. Sommige Nederlandse steden hadden al veel eerder een eigen boomsnoeier in dienst, Schiedam bijvoorbeeld sinds 1757: Medema, Achter de façade, 193.

36 SAA, MA \#951: Bruynseels aan College, 9 augustus 1832 en Bruynseels aan College, 11 maart [183?]. tot 'toute leur valeur' volgroeid, kapte men de bomen best om de stadskas te spijzen. De omslag naar straatbomen als vooreerst decoratieve elementen voltrok zich duidelijk geleidelijk. Omdat de commissie niet het laatste woord kreeg, gaven de betrokken raadsleden er enkele weken na hun blauwdruk echter de brui aan. ${ }^{37}$ Wat qua groenbeleid in de decennia nadien tot stand kwam, had een onmiskenbaar ad hoc-karakter, waarbij tuinmannen meer dan eens de speelbal van de inspecteur van stadswerken en de stadsarchitect werden. Voor kleinschalige ondernemingen volstond een impliciete taakverdeling, maar zodra grotere projecten op tafel lagen, botste het model op zijn grenzen, al dient gezegd dat het improvisatorisch gehalte elders doorgaans nog veel groter was - in Brussel stond niet eens een tuinman op de stedelijke loonlijst. ${ }^{38}$

\section{Spanningen tussen functionaliteit en decoratie}

Dat het tot halverwege de negentiende eeuw in Antwerpen noch elders in België tot ingrijpende realisaties van openbaar groen kwam, had veel te maken met de uitgesproken liberale geest. Waar sterke autocraten met één pennentrek hele wijken konden platleggen, lagen drastische maatregelen moeilijker in samenlevingen met een bescherming van het individuele eigendomsrecht. Er waren enkele dramatische crises nodig, zoals de uitbraken van cholera in 1866 en 1884 , vooraleer met name gezondheidsoverwegingen een rol

\footnotetext{
37 SAA, MA \#952: rapport over de stedelijke aanplantingen, 31 maart 1833; Vanderlinden-Delloye en Ceulemans aan burgemeester, 4 mei 1833 . 38 A. Stynen, Proeftuinen, 441-450.
} 
in stadsplanning kregen. Groen was, opvallend genoeg, tot de Eerste Wereldoorlog geen wezenlijk middel tot het verbeteren van de volksgezondheid in Belgische steden: om de ophoping van 'pestilente dampen' en stof te vermijden, ging men vooral over tot een scherper toezicht op bouwvoorschriften en tot ontsmettingsmaatregelen zoals het overkappen van waterlopen. ${ }^{39}$

De al bij al zwakke positie van lokale bestuurders nam een wending omstreeks 1860. Een nieuwe wet op onteigeningen stipuleerde in $185^{8}$ dat meeropbrengsten niet langer naar de oorspronkelijke eigenaar terugvloeiden, terwijl een aanvulling op deze wet in 1867 een soepelere motivatie voor expropriations naar voren schoof. $^{40}$ Ongetwijfeld geïnspireerd door de krachtdadige transformatie van Parijs door prefect Haussmann konden stadsbesturen nu zowel de bebouwde ruimte als de groenruimte met een grotere radicaliteit vormgeven. Daarbovenop maakten twee ingrepen dat de stad uit een decennialang carcan kon breken. Enerzijds was er in 1860 de afschaffing van de octrooibelasting, waardoor de 'harde' stadsgrenzen van grachten, wallen en poorten overal in België verdwenen. Anderzijds maakten moderne militaire technieken de oude vestingmuren zinloos en lokale overheden popelden om deze terreinen in de stad te integreren. De nationale regering maakte van Antwerpen echter de cruciale pijler van de landsverdediging. Pas na jarenlange discussies besloot het Parlement in 1859 tot een nieuwe verdedigingsmuur,

39 Stad Antwerpen, Gemeentebulletyn, 1866/I, 641, 1866/II, 670-671 en 1884/II, 25-31.

$40 \mathrm{Ph}$. Godding, 'L'évolution de la législation en matière d'urbanisme en Belgique au XIXe siècle', in : Villes en mutation XIXe-XXe siècles. 1oe colloque international. Spa, 2-5 sept. 1980. Actes (Brussel 1982) 24-29. verder van het centrum. Vijf jaar later werd de oude gordel aan het stadsbestuur overgedragen, niets minder dan 'de aenbreking van een nieuw tydvak', zeker ook inzake groenvoorziening. ${ }^{41}$

Voordien was al over de invulling van de militaire zone gedebatteerd. Zo klonken in de vroege jaren 1840 pleidooien voor een promenade op een segment van de glooiende omwalling, een idee dat in 1844 door Pierre Bourla werd opgepikt. Hoewel enkel om een kostenberekening gevraagd, presenteerde de stadsarchitect het stadsbestuur een idyllische visie, met druk bezochte herbergen in het groen. Ondanks scepticisme in de gemeenteraad - sommigen achtten het verschaffen van vermaak geen overheidstaak - werd het plan goedgekeurd, met als doorslaggevend argument dat Antwerpen niet op andere steden mocht achterblijven. ${ }^{42} \mathrm{Ge}$ meenteraadslid Emmanuel Van Cuyck, die nog maar net de tuin van de Société de zoölogie had uitgewerkt (enkel voor leden of anders tegen betaling te bezoeken), mocht de plannen uittekenen. Aan de stadsrand, voor iedereen toegankelijk, legde Van Cuyck een open landschap aan dat van visueel raffinement getuigde: zowel de bomen als de omgeving, maar ook de passage van karren en ruiters maakten deel uit van het spektakel - de recreatie was fundamenteel visueel. ${ }^{43}$ De wandeling aan het glacis werd weldra erg populair. Hierdoor gesterkt breidde het stadsbestuur de wandelplek de komende jaren verder uit, rondom het driehoekige fort Herentals. Inspiratie kwam uit de grote

41 Stad Antwerpen, Gemeentebulletyn, 1864/II, 101103.

42 SAA, MA \#953: Bourla aan College, 26 juli 1844; notulen raadsvergadering, 28 september 1844 .

43 SAA, MA \#953: commissieverslag, 15 november 1845; notulen raadsvergadering, 15 november 1845 . 
Parijse parken die men wilde 'imiter dans les petites choses' ${ }^{44}$

De Antwerpse bevolking eigende zich de publieke wandelruimte enthousiast toe. Ze kon zich vinden in het maatschappijbeeld van haar bestuurders, met een vrije toegang en een verzoening van een stedelijk en landelijk milieu als kernpunten die nu in de ruimte zelf tot uitdrukking kwamen. ${ }^{45}$ Tegelijkertijd meende men dat die betrokkenheid ook inspraak impliceerde. Groot was daarom de consternatie toen stadsingenieur Theodoor Van Bever in juli 1864 een rapport indiende met daarin het voorstel van een brede verkeersader op het tracé van de oude gordel. ${ }^{46}$ Van Bever bepleitte dan wel de omvorming van fort Herentals tot één groot park, zijn plan betekende het verdwijnen van de geliefde wandelplek langs het glacis. Terwijl het havenluik uit het project niet minder ambitieus was, werd vooral over de groenvoorziening maandenlang gedebatteerd. Voorstanders poneerden dat een vlotte doorstroming onontbeerlijk was, terwijl de oppositie voor een monotone stad zonder charme waarschuwde. Een commissie dreef de tegenstellingen enkel op de spits en ontlokte de redactie van het gezagsgetrouwe Handelsblad de boutade dat 'de belangen der handelstad' moesten primeren op 'die der wandelstad'. Wie het niet met deze

44 SAA, MA \#955/1: nota van 22 oktober 1859. Zie voor de doorbraak van stadsparken F. Debié, Jardins de capitales. Une géographie des parcs et jardins publics de Paris, Londres, Vienne et Berlin (Parijs 1992). 45 Dit gebruik van het stedelijke landschap als 'a canvas on which to paint [...] social theories' (14) werd voor het achttiende tot twintigste-eeuwse Wenen systematisch geanalyseerd door Robert Rotenberg in zijn Landscape and power in Vienna (Londen en Baltimore 2005).

46 Stad Antwerpen, Gemeentebulletyn, 1864/II, 101114. hiërarchie eens was, had het slecht voor met zijn vaderstad. ${ }^{47}$ Talrijk waren de ontwerpers die stad en groen met elkaar wilden vervlechten. Duidelijk was dat de oude promenade de stad diep verdeelde - zelfs de nieuwe stadsarchitect Pieter Dens haalde uit naar Van Bever. ${ }^{48}$ Verhitte discussies in de gemeenteraad vonden weerklank in de kranten. Het liberale dagblad Grondwet deed een beroep op zijn lezers om bezwaarschriften in te dienen. ${ }^{49}$ En zo gebeurde, en masse zelfs: begin 1865 lagen verschillende petities op tafel, één met liefst zesduizend handtekeningen voor het behoud van Van Cuycks wandeling. Het stadsbestuur veegde deze echter als irrelevant van tafel, met het verwijt enkel een partijpolitieke manoeuvre te zijn. Twee dagen vol bitse debatten later viel finaal het doek over het glacis. ${ }^{50}$ Hoe zuur deze nederlaag bij tegenstanders viel, blijkt uit Le Précurseur, die een opsomming gaf van alle raadsleden die men later aansprakelijk zou stellen voor de onvermijdelijke neergang van Antwerpen. ${ }^{51}$

De weerstand verklaart zich deels door de vele vraagtekens bij Van Bevers alternatief: de transformatie van het oude fort lag allerminst vast - zelfs voorstanders noemden het een keuze van het verstand en niet van het hart. Terwijl Dens expliciet verkondigde dat het ontwerp hem 'en droit ligne' toekwam, bepleitte Van Bever de inbreng van een gerenommeerde tuinarchitect. ${ }^{52} \mathrm{Na}$ veel uitstel drong begin 1867 het besef door dat de stad noch over

47 Het Handelsblad, 21 september 1864. 48 Stad Antwerpen, Gemeentebulletyn, 1864/II, 752754 .

49 De Grondwet, 29 december 1864 en 3 januari 1865. 50 Stad Antwerpen, Gemeentebulletyn, 4 januari 1865 , 2-3 en 5 januari 1865, 64-67 en 73-79.

$51 \quad$ Le Précurseur, 6 januari 1865. 52 SAA, MA \#956/5: Dens aan College, 3 januari 1866. 
het personeel, noch over het instrumentarium beschikte om een dergelijk project aan te vatten. In geheime beraadslagingen werden middelen vrijgemaakt om Eduard Keilig, die onder andere in het Brusselse Terkamerenbos (1862) zijn kunnen had bewezen, in te schakelen. ${ }^{53}$ Dat die keuze een aanzienlijke meerkost betekende, zette opnieuw kwaad bloed: de oppositie merkte schamper op dat het beloofde nieuwe aardsche Paradijs' wel heel ver weg leek. ${ }^{54}$ Naarmate Keilig vorderde in de zomer van 1869 was het stadspark klaar - bleek zijn plan wel degelijk hoofdstedelijke allures te hebben. En toch bleef de twijfel. Toen Keilig ook de omringende lanen met bomen en struiken wilde verfraaien, rees protest. Sommigen, nog altijd misnoegd over het glacis, veroordeelden het rooien van de bestaande bomenrijen, naar hun zeggen de laatste plek in Antwerpen met schaduw. Als in een echo aan vroegere attitudes tekenden omwonenden dan weer bezwaar aan dat hun luxueuze gevels aan het zicht werden onttrokken, waarop burgemeester Jozef Van Put repliceerde dat zij juist 'réellement dans le Parc' zouden wonen. Met een grote meerderheid kreeg ook dit plan groen licht, waarna de debatten rond het stadspark verstomden. ${ }^{55}$

In het officiële discours over de aanleg van stedelijk groen werd er nauwelijks aandacht besteed aan recreatie. Het stadspark werd in de eerste plaats ingezet in de verfraaiing van de stad, de verhoging van haar prestige en het voorzien in de vraag

53 SAA, MA \#956/5: PV geheime beraadslaging Raad, 13 april 1867 . Zie voor de aanleg van het stadspark ook K. Hebbelinck, 'Friedrich Eduard Keilig en het stadspark van Antwerpen', Monumenten, Landschappen \& Archeologie 28.2 (2009) 46-70.

54 De Koophandel, 4 en 5 november 1867.

55 Stad Antwerpen, Gemeenteblad, 1869/I, 9-45. naar (visueel) vermaak. Vanaf de opening in 1869 vonden er in het stadspark regelmatig concerten, wedstrijden en stoeten plaats. Het ging echter steeds om streng gecontroleerde en door het stadsbestuur of door de burgerlijke verenigingen georganiseerde activiteiten met een beschaafd en deftig karakter. Toch zorgden zelfs burgerlijke recreatievormen voor de nodige discussies en gefronste wenkbrauwen bij het stadsbestuur. Een uitvinding die opschudding veroorzaakte was de trapper, die de rage van de fiets initieerde. Enkele gemeenteraadsleden wilden fietsers verbieden in alle wandelingen, waaronder het stadspark. Hoewel fietsen een luxegoed waren, bezaten ze het potentieel om de burgerlijke atmosfeer in de publieke groenzones te verstoren. De trapwagenvoerders werden beschouwd als een gevaar voor wandelaars, paarden en beplantingen. Hoewel fietsen tijdens de laatste decennia van de negentiende eeuw (ook voor vrouwen) een erg populair tijdverdrijf werd, duidt de aarzelende houding van het stadsbestuur op het problematisch karakter van recreatie in het stadspark. Naar aanleiding van de rage van de fiets werd het reglement op de openbare wandelingen in 1870 aangepast. Uit het reglement spreekt een afkeer voor actieve recreatie:

Het is verboden met paarden, vee, rijtuigen, trapwagens, hondenspannen en kruiwagens te komen $[\ldots]$ in de wegen voor voetgangers in het park. [...] Het is verboden $[. .$.$] te spelen; samenscholin-$ gen te weeg te brengen die den doorgang kunnen verhinderen; vuilnis te werpen of iets te doen wat met de eerbaarheid strijdt; te visschen, te baden of dieren te laten baden in de vijverwaters. [...] Zon- 


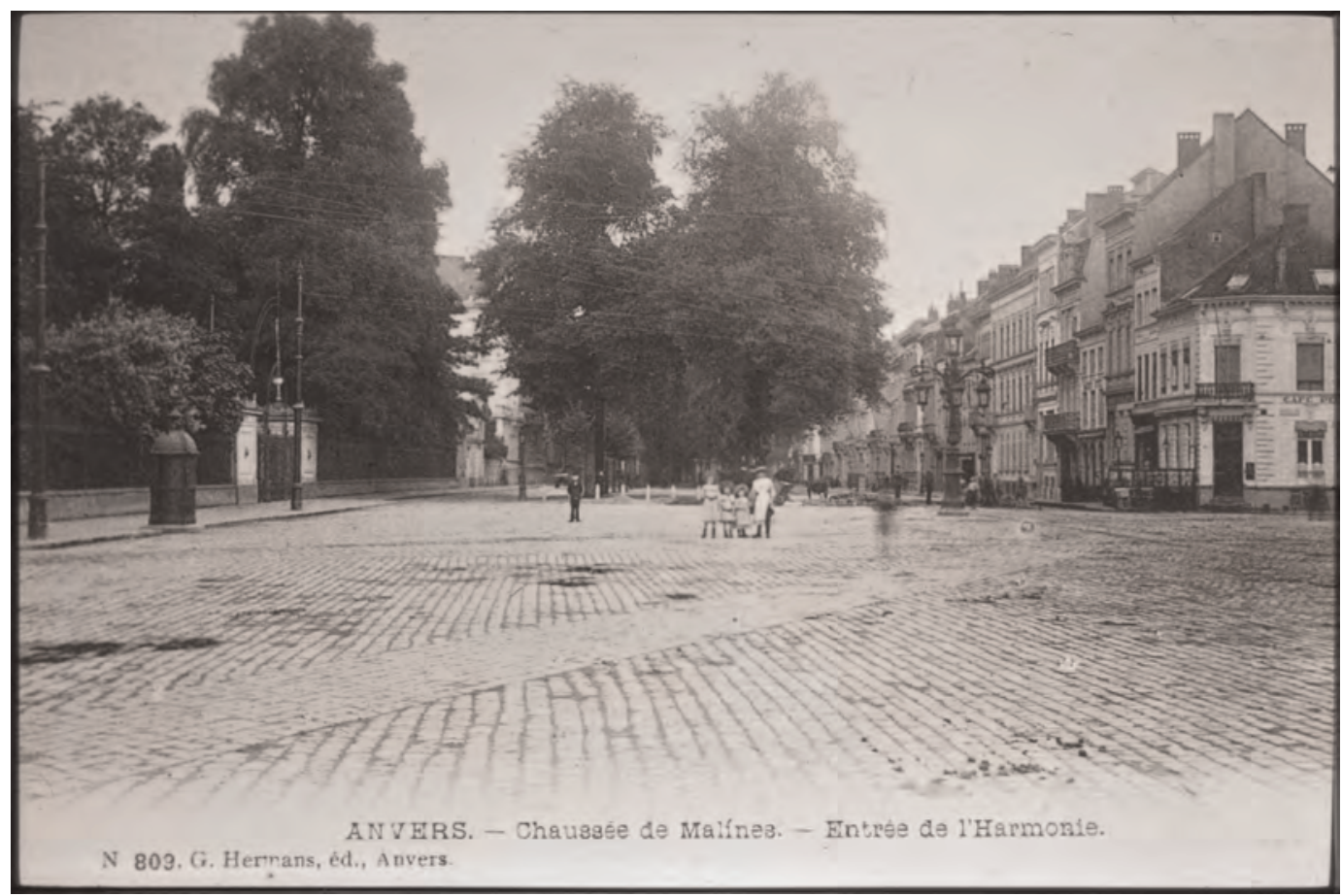

De ingang van het Harmoniepark en de Mechelsesteenweg, ca. 1900

Stadsarchief Antwerpen

der vergunning van Burgemeester en Schepenen mogen in het park en de warande geene kramen opgeslagen of schouwpelen vertoond worden. ${ }^{56}$

Het stadsbestuur bouwde een kwaliteitscontrole in op de activiteiten die in de openbare parken plaatsvonden. Alle verwijzingen naar arbeid werden uit het park gebannen, en acties die de rust in het park zouden kunnen schaden werden verboden. Ondanks het erg strikte reglement zorgt een eenzijdige focus op de officiële visie op het parkgebruik voor een onscherpe blik op de laatnegentiende-eeuwse groenzones. Een niet te onderschatten element bij het bestuderen van de stedelijk (groen)ruimte is de beleving van officieel, openbaar groen vanuit het perspectief van de gebruikers. Individuele herin-

56 Stad Antwerpen, Gemeenteblad, 1870/II, 315-318. neringen van stadsbewoners bieden een alternatief perspectief op de beleving van stedelijk groen.

In de bundel Weerspiegeld Antwerpen zijn enkele bijdragen gewijd aan de herinneringen van Antwerpenaren die tijdens hun jeugdjaren in de omgeving van het stadspark woonden. De omgeving rond het nieuwe park was geheel in lijn met de verwachtingen van het stadsbestuur en de stadsingenieur 'een stille buurt, door stille menschen bewoond: professors, stadsbeambten, renteniers, kooplieden' ${ }^{57}$ Louisa Duykers besteedde vooral aandacht aan de aantrekkingskracht van het park als speelruimte. 'Door de fata morgana der jaren gezien, komt het me voor alsof heel mijne kinderjaren, heel

57 L. Duykers, 'Het Park', in: Weerspiegeld Antwerpen. Hoe 't vroeger was: onze schrijvers over hun stad (Antwerpen 1929) 283 . 
mijne jeugd zich in het park hebben afgespeeld. Nooit verloor het voor mij zijne bekoring, nooit werden zijne mogelijkheden uitgeput. ${ }^{58}$ Ondanks de strikte parkreglementen - het reglement uit 1870 werd in licht gewijzigde vorm opnieuw bekrachtigd in $1894^{59}$ - en de bewaking door de politie en de gardevilles konden kinderen ongestoord kattenkwaad uithalen in het stijfdeftige park.

Hoe dikwijls hebben we verstoppertje gespeeld achter de boomen en in de boschjes, of in 't rondpunt, achter Door Van Rijswijck's standbeeld dat daar nog in een vergeten hoek stond? Hoe dikwerf hebben we langs de groote lanen met onze hoepels geloopen, of zijn we den berg afgebold in wilde, halsbrekende vaart van de brug naar het water, en niet altijd langs de wegen! ${ }^{60}$

Het verbod op spelen werd genegeerd, maar ook het betreden van grasvelden en plantsoenen, en het beklimmen van omheiningen en standbeelden kon ongestoord gebeuren. Het is niet verwonderlijk dat de parkregels omzeild werden, maar bronnen als Weerspiegeld Antwerpen geven voor het eerst een direct inzicht in de gelaagde beleving van stedelijk groen. Niet alleen kinderen durfden de regels in de openbare wandelingen aan hun laars lappen. Tijdens de concerten op zondag maakten kindermeisjes en soldaten dankbaar gebruik van de dichtbegroeide omgeving om ongestoord samen te zijn. ${ }^{61}$ Het park was bovendien een ruimte waar de

58 Duykers, 'Het park', 285.

59 SAA, MA 571\#23: Verordening op de openbare wandelingen, reglement van 26 juli 1894 .

6o Duykers, 'Het park', 285.

61 A. De Lattin, Sinjorenstad 1880-19oo (Antwerpen 1944) 38. verschillende lagen van de bevolking zich verenigden. Auguste Cleykens belichtte tijdens zijn stadswandeling in 1905 de personen die hij in het park tegenkwam. Hij ontmoette een man met tuberculose, groepjes werkloze dienstmeisjes en dagloners die zich verdiepten in de vacaturepagina's, een dronkaard die luid vloekend en voorbijgangers schofferend uit het park werd gezet door de politie, en een groepje zieke ouderlingen die even konden genieten van de buitenlucht. ${ }^{62}$ De beschrijvingen tonen aan dat zelfs in een stedelijke ruimte die geconcipieerd werd als een uitermate burgerlijke omgeving, en die streng gecontroleerd en gereguleerd werd, verschillende lagen van de bevolking zich vermengden. Het Antwerpse stadspark vormde naast een geliefkoosde wandelplaats en een place m'as tu $v u$ ook een toevluchtsoord voor dronkaards, zwervers en werklozen.

\section{Spanningen over squares en straatbomen}

Grote groenzones als het stadspark en de in 1876 heraangelegde Warande noopten het stadsbestuur tot controle op de bezoekers, maar ook op de ruimte zelf. Zonder voortdurend onderhoud zou de natuur er spoedig uit haar keurslijf breken. De jaren 186o waren een kantelmoment. Ambitieuze projecten als het Terkamerenbos en de schaduwrijke Louizalaan maakten in Brussel de aanwerving van een inspecteur des plantations met eigen personeel onontbeerlijk. In Antwerpen gaven twee rapporten uit 1870 de aanzet tot een gelijkaardige professionalisering, initieel zonder

62 A. Cleykens, Tableaux anversois. Scènes de moeurs, types et paysage (Antwerpen 1905), 32-46. 
apart diensthoofd weliswaar. Stadsingenieur Van Bever, die na een lange machtsstrijd met de stedelijke architect aan het langste eind trok, achtte zijn expertise afdoende. ${ }^{63}$ Onterecht, zo bleek al gauw, en toen in afwezigheid van een doodzieke Van Bever de drieëntwintigjarige tuinbouwer Henri de Bosschere in 1874 aanbood om kosteloos 'het bestuur der wandelwegen' op te nemen, maakte het stadsbestuur graag van deze opportuniteit gebruik. Op 1 maart 1876 werd De Bosschere de eerste (bezoldigde) inspecteur voor aanplantingen. Zijn autonome dienst rapporteerde rechtstreeks aan het College, dat spoedig een stevige budgetverhoging voor aanplantingen doorvoerde. ${ }^{64}$

De professionalisering van het groenbeleid kwam voort uit het verlangen om van aanplantingen een bestuurlijk uithangbord te maken. Een proliferatie van stadsnatuur over het stedelijke weefsel volgde. Die evolutie was op Parijse leest geschoeid: de transformatie van de Franse hoofdstad had een groene component, vooral het werk van ingénieur-jardinier Jean-Charles Alphand. Op zijn aangeven werd de Parijse agglomeratie met tweeduizend hectare groen uitgebreid, grote parken maar ook talloze kleinere tuinen, plantsoenen en squares en bomen langs prestigieuze boulevards, geheel volgens verticale hiërarchie. ${ }^{65}$ Dergelijke top-

63 SAA, MA \#1361/1: rapport van commissies wegenis en werken, januari 1870; MA 1364/1: commissieverslag, 24 september 1870 . Zie voor de spanningen tussen stadsingenieur en stadsarchitect: I. Bertels, Building the city, Antwerp 1819-1880 (onuitgegeven doctoraatsverhandeling KU Leuven 2008) 101-115.

64 Stad Antwerpen, Gemeenteblad, 1874/II, 396; SAA, MA \#956/8: burgemeester Leopold De Wael aan De Bosschere, 2 maart 1875 .

65 G. Texier-Rideau, 'Le square haussmannien', in: S. Texier ed., Les parcs et jardins dans l'urbanisme parisien, XIXe-XXe siècles (Parijs 2001) 69. down-coördinatie en rationele systematiek ontbraken in België, maar de ambitieuze De Bosschere poogde waar mogelijk groen in het Antwerpse straatbeeld te integreren. Squares, in oorsprong enkel voor omwonenden toegankelijke perken in elitaire zeventiende-eeuwse Londense wijken, waren een middel om op kleine schaal snel in openbaar groen te voorzien. ${ }^{66}$ De sociale en hygiënische argumenten waarmee, naast de esthetische troeven, in het buitenland voor deze aanplantingen werden gepleit, vonden in België weinig gehoor. Zo bleef een vroeg plan voor een square op het Antwerpse SintWalburgisplein in de jaren 1840 wegens de hoge kostprijs onuitgevoerd, een situatie die zich in 1867 herhaalde toen Dens plannen voor een square op de Groenplaats voorlegde. ${ }^{67}$ De kentering volgde echter kort nadien, toen Brussel de toon al had gezet en De Bosschere met kosteloos uitgetekende plantsoenen op de Gemeenteplaats zijn aanwerving veilig stelde. ${ }^{68}$ De Bosschere verwees expliciet naar het prestige voor de stad: 'In al de groote steden wordt van het minste pleintje gebruik gemaakt om eene square aan te leggen; omdat zulks het kwartier verlevendigt, gezond en aangenaam maakt. ${ }^{, 69}$ Deze argumentatie sloeg aan en hij mocht de volgende jaren her en der plantsoenen en soms heuse parkjes aanplanten, zij het enkel in stadsdelen met respectabele burgers. Hoewel artsen tegen het einde van de eeuw de hygiënische weldaden van stadsgroen voorzichtig begonnen te prij-

66 T. Longstaffe-Gowan, The London town garden 1740-1840 (New Haven en Londen 2001) 183-188. 67 SAA, MA \#956/8: College aan Bourla, 17 september 1840; MA 1361/3: Dens aan College, 6 september 1867. 68 Stad Antwerpen, Gemeenteblad, 1875/I, 289-291. 69 SAA, MA \#956/8: De Bosschere aan College, $3^{\circ}$ oktober 1879 . 


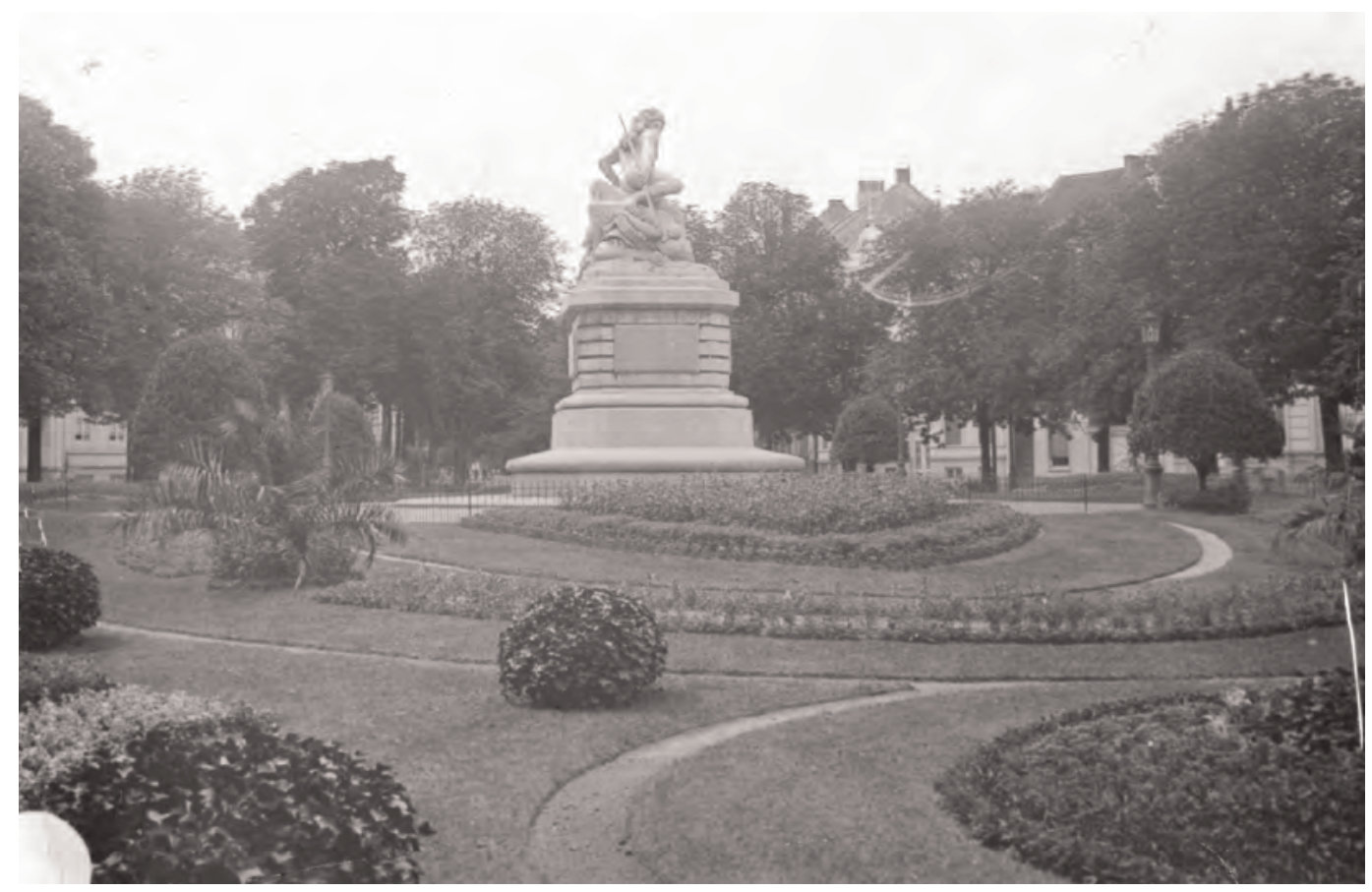

De square aan de Leopoldslei (huidige Belgiëlei), met het in 1954 verwijderde standbeeld van de Boduognat, leider van de Nerviërs

Stadsarchief Antwerpen

zen, speelde dit argument voor politici geen rol van betekenis. Veelzeggend is hoe burgemeester Jan Van Rijswijck bij zijn aantreden in 1892 volksgezondheid de eerste prioriteit noemde en drie maanden later een mogelijke square in de Stuivenbergwijk zonder aarzelen als 'minder belangrijk' omschreef dan de overwelving van de Schijn, een vervuilde waterloop. ${ }^{70}$

Was de tevredenheid over squares doorgaans groot, dan waren straatbomen vaak meer omstreden. Dat bleek in $185^{8}$, bij plannen om de Leopoldslei (thans Belgiëlei) met vier rijen olmen en kastanjelaren te beplanten. ${ }^{71}$ Huiseigenaars protes-

70 Stad Antwerpen, Gemeenteblad, 1892/II, 231 en 1893/I, 170-171.

71 Zie voor deze casus A. Stynen, 'Omstreden nieuwkomers. Bomen in het Antwerpse straatbeeld (18501914)', Tijd-Schrift 4.2 (2014) 22-25. teerden omdat ze door geringere zichtbaarheid waardeverlies vreesden. Het project werd evenwel uitgevoerd en oogstte veel lof, tot De Bosschere in 1876 signaleerde dat de opschietende bomen elkaar begonnen te verstikken. Niettemin kostte het hem tien jaar om de overheid te overtuigen de kastanjelaren te kappen. Met beperkt succes, zo moest men nog een decennium later toegeven: de olmen hadden de vrijgekomen plaatsen ingepalmd en nu waren zij de bewoners tot last. Om het probleem structureel te verhelpen, schoof De Bosschere een ingrijpende oplossing naar voren: twee van de vier rijen moesten wijken. De reactie was opvallend: stootten de vier rijen oorspronkelijk op verzet, dan werd in de jaren 1890 met veel vuur tegen het 'massacreeren' van de bomen gepleit. Destijds ging het vooral 
over problemen van vocht en een tekort aan licht en lucht, maar die bedenkingen werden aan het einde van de eeuw volledig overstemd door niets minder dan een vorm van empathie met de 'malheureux arbres'. ${ }^{72}$ Het stadsbestuur aarzelde, tot nieuwe klachten over het duistere bladerdek de beplanting van de Leopoldslei rond 1900 opnieuw op de agenda plaatsten. Met een bijzondere snoeimethode trachtte De Bosschere meer licht te brengen, een ingreep die met niet minder onbegrip werd onthaald: de bevolking die ooit in het beste geval nog onverschillig tegen straatbomen had gestaan, herkende in deze aanplantingen nu niet alleen een decoratieve functie, maar ook een brug naar ongerepte natuur. Deze prille ecologische bekommernis was een verschuiving die het werk van De Bosschere en zijn dienst danig bemoeilijkte.

Hoewel de stad in de ban was van een vlaag van squaremania en stadsgroen op een zekere emotionele gehechtheid van de bevolking kon rekenen, stond of viel het prestige van de stad met de gepaste omgang van de bevolking met de stedelijke ruimte. Het is niet verwonderlijk dat er een reactie ontstond vanuit de stadsbevolking, die zich niet kon vinden in de strak aangelegde, ontoegankelijke squares. Het stadsbestuur kreeg naast de vraag tot het creëren van verschillende vormen van recreatieve infrastructuur in de stedelijke groenruimtes, regelmatig af te rekenen met de ongewenste effecten van een streng gecontroleerde ruimte. Het probleem van vandalisme in de stedelijke

72 Het Handelsblad, 4 januari 1895; Le Matin, 8 januari 1895 .

73 Stad Antwerpen, Gemeenteblad, 1870/II, 315-318. Het reglement bestond al sinds 1844 en werd aangepast in 1848 en 1860 en 1870 en opnieuw bestendigd in 1894 . groenruimtes werd met de regelmaat van de klok bediscussieerd in de Antwerpse gemeenteraad. In het reglement op de openbare wandelingen werd elke vorm van beschadiging dan ook strafbaar. ${ }^{73} \mathrm{Er}$ werd echter geregeld geklaagd over de honden die toch in de vijver van het park zwommen. Wandelaars werden 'bespat en bevuild' door de dieren, wat als zeer onaangenaam ervaren werd. ${ }^{74}$ Er werd voorgesteld om, naar analogie met andere steden, een reglement op te stellen dat mensen verplichtte hun hond aan de leiband te houden. De squares in de stad hadden immers te lijden onder de nonchalance van de hondeneigenaars. 'Pas is een bloemenperk aangelegd of de honden loopen en spelen er in en vernielen de planten. Sommige eigenaren van honden vinden dat zelfs vermakelijk. ${ }^{, 75}$

De grootste stoorzenders in de publieke groenruimtes waren volgens de bestuurders echter de gamins of 'kwaêjongens'. Tijdens de discussie over de transformatie van de Groenplaats in 1872 werd het planten van kastanjes op het plein door verschillende raadsleden als een groot gevaar beschouwd. 'Les marronniers offrent un grand désavantage, résultant de leurs fruits, qui servent de projectiles aux gamins. ${ }^{76}$ De burgemeester en zijn buren in de Leopoldslei konden er naar eigen zeggen van meespreken: 'Il ne passe pas de jour, que des promeneurs ne reçoivent des marrons, je ne dirai pas entre les jambes, mais contre la tête'. Er werd aan toegevoegd dat er bij het kastanjegooien regelmatig ramen sneuvelden, omdat de jongens stenen gebruikten om de kastanjes uit de bomen te gooien. Kastanjelaren

\footnotetext{
74 Stad Antwerpen, Gemeenteblad, 1879/I, 356. 75 Ibidem, 356. 76 Stad Antwerpen, Gemeenteblad, 1872/II, 357.
} 
werden beschouwd als erg mooie bomen, maar ze hoorden enkel thuis op plaatsen waar voldoende politiebewaking was. Op de Groenplaats kregen de kwajongens het bijvoorbeeld in hun hoofd om voorbijgangers te bekogelen. In de vroege herfst van 1882 werd er een voorstel gelanceerd om de kastanjes 'van ambtswege' uit de bomen te laten halen. Net zoals alle voorgaande jaren maakten de jongens jacht op de kastanjes, maar terwijl ze voordien met stukken hout of stenen gooiden, hadden ze nu de kasseien ontdekt. ${ }^{77}$ In 1891 kwam men met de ideale oplossing: 'kastanieboomen zonder vruchten $[\ldots]$ - eene nieuwe soort, waartegen de kwaêjongens geene steenen zullen smijten'. ${ }^{78}$

De kastanjejacht was een relatief onschuldige vorm van wangedrag. Squares die in dichtbevolktere en aan minder politiecontrole onderworpen buurten gelegen waren, kregen het zwaarder te verduren. De square op het De Coninckplein, aangelegd in 1877 , bevond zich in 1894 'in erbarmelijken toestand'. De vraag werd opgeworpen of het tuintje niet beter vervangen zou worden door een gekasseid plein. 'Thans is zij letterlijk prijs gegeven aan de straatloopers en hare verwoesting doet pijn ter harte.' Het argument dat er te weinig politiebewaking zou zijn, ging volgens burgemeester Van Rijswijck niet op. Elke week werden er meerdere processen-verbaal opgemaakt, maar het strenge optreden van de politie mocht niet baten: 'De vernielingszucht schijnt den mensch ingeboren'. De burgemeester deed zijn reputatie als man van het volk alle eer aan door te benadrukken dat het niet alleen de volkskinderen uit de buurt waren die de vernielingen aanbrachten, en dat de

77 Stad Antwerpen, Gemeenteblad, 1882/II, 427-428. 78 Stad Antwerpen, Gemeenteblad, 1891/II, 257-258.
Antwerpse jeugd geen uitzondering was, maar hij zag in dat de situatie onhoudbaar was: 'Als de politie de rug gekeerd heeft, begint de vernieling'. ${ }^{79}$

Het is opvallend dat de squares die het onderwerp van discussie waren vanwege steeds terugkerend vandalisme allemaal in dichtbevolkte arbeidersbuurten gelegen waren. Naast het De Coninckplein kwamen het Sint-Jansplein, het Stuivenbergplein en de Van Rijswijckplaats aan bod. De omgeving van het De Coninckplein, waar in de tweede helft van de negentiende eeuw verschillende sociale woningcomplexen gebouwd werden, stond bekend als een arbeiderswijk, net als de Van Rijswijckplaats, die in 'smerig SintAndries' lag. Op het Sint-Jansplein 'qui constitue une grande ressource pour la population ouvrière entassée dans les rues populeuses qui avoisinent la place St-Jean', werden de bomen keer op keer vernield, en het Stuivenbergkerkhof, gelegen in om zijn ruige, volkse karakter gekende randwijk of faboert (afgeleid van het Franse faubourg), kampte met hetzelfde probleem. ${ }^{80}$ De squares bevonden zich allemaal in verwaarloosde toestand, hoewel ze hetzelfde onderhoud kregen als alle andere squares in de stad. Het vandalismeprobleem toont erg helder aan dat groenprojecten, en vooral squares, op een al te naïef maatschappijbeeld gebouwd waren.

79 Stad Antwerpen, Gemeenteblad, 1894/II, 309.

80 SAA, MA 571\#32: Willems aan College, 11 januari 1895; Stad Antwerpen, Gemeenteblad, 1895/I, 185. 


\section{Het belang van geïmproviseerd groen}

De discussies in de gemeenteraad waren tijdens de negentiende eeuw steeds gefocust op de decoratie en het prestige van de stad en haar internationale concurrentiepositie. Terwijl er internationaal steeds meer aandacht werd besteed aan de recreatieve infrastructuur in publieke groenruimtes, bleef het Antwerpse stadsbestuur erg weigerachtig. De neiging tot vandalisme in de groenruimtes geeft aan in welke mate de officiële beslissingen over stedelijk groen haaks stonden op de noden en wensen van de stadsbewoners. De discussies over de recreatieve infrastructuur in de stad, die door het bestuur ingezet werd als een element om het prestige en het grootstedelijk karakter van Antwerpen te bestendigen, tonen bovendien aan in welke mate het discours van het stadsbestuur zich boven de hoofden van de bewoners afspeelde. De strikte invulling van de officiële groenruimtes werd al genuanceerd door de beleving van de stadsbewoners. Een tweede nuancering op het al te sterk door officieel discours gestuurde onderzoek naar stedelijk groen is de studie van officieuze groenruimtes. De erg strikte reglementen op de openbare wandelingen waren immers niet van toepassing op geimproviseerde groenruimtes.

Aan het einde van de negentiende eeuw kampte Antwerpen met de reputatie van Europese stad met de minste openbare groenruimte. ${ }^{81}$ De stad, die op dat moment bijna 300.000 inwoners telde, be-

81 A. Delbeke, 'Ouverture solennelle de l'exposition du concours', in Commission d'études pour l'aménagement de l'Agglomération Anversoise ed., Concours pour l'aménagement des terrains devenant disponibles par suite du démantèlement de l'enceinte fortifiée d'Anvers (Antwerpen 1911) 93. schikte slechts over twee publieke parken, een dierentuin en enkele kleinere groene pleinen en squares. Hoewel de bevolkingsdruk in bepaalde wijken zeer groot was, werd het groentekort niet als een acuut probleem aangevoeld en is het treffend hoeveel aandacht er in de stadsbelevingen besteed werd aan stedelijk groen. De meeste auteurs in Weerspiegeld Antwerpen beschrijven hun jeugd in de stad voor de aanvang van de twintigste eeuw, en hoewel er in die periode nauwelijks (positieve) aandacht was voor kinderen in de stedelijke ruimte, beschrijven ze bijna allemaal de publieke (groene) ruimtes waar ze als kind speelden. Ook de beleving van volwassenen in de stad werd in hoge mate bepaald door hun gebruik van groene ruimtes in de stad.

Binnen de stadsgrenzen waren aan het einde van de negentiende eeuw nog heel wat braakliggende gronden ter beschikking. Aangezien er nauwelijks officiële speelruimte voorhanden was in de stad, creëerden kinderen hun eigen speeltuin. John Broeders beschreef het gebruik van de braakliggende gronden rondom de Stuivenberg: 'Duizenden kinderen krioelden en ravotten daar door elkaar op rusten feestdagen en gedurende de eerste weken na het binnenroepen der jaarlijksche lichtingen werden er gansche bataillons schachten gedrild onder het critisch oog van oude lieden, leegloopers en knapen. ${ }^{, 82}$ De braakliggende gronden in de omgeving van het Stuivenbergplein waren echter ook een aantrekkingspool voor 'miserielijders en landloopers en receptakel voor al-

82 J. Broeders, 'Het faboert', in: Weerspiegeld Antwerpen, 153 . 83 Ibidem, 154. 


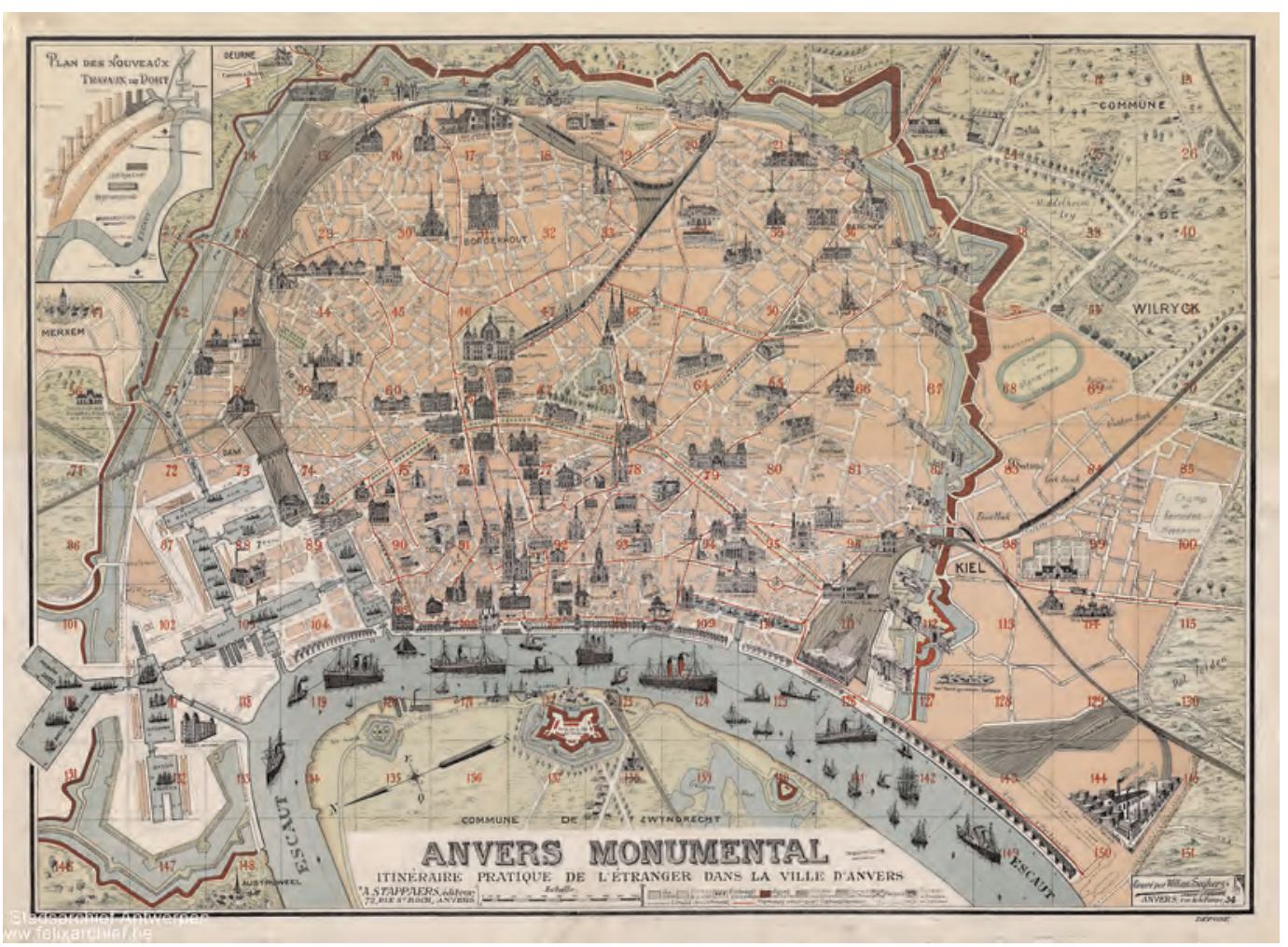

A. Stappaers en Seghers, kaart van Antwerpen, ca. 1908

Stadsarchief Antwerpen

lerlei kwalijkriekenden afval'. ${ }^{83}$ Een grote open ruimte die erg bekend was, lag aan de huidige Italiëlei. 'In het oostelijke gedeelte, waar ik woonde, paalde elk der beide hoekkompleksen aldus aan een onbebouwden lap gronds. In de wandeling noemde men het zuiderstuk de "kiekenwei", het andere, kortàf, de "wei".,84 De toegang tot het braakland was officieel verboden, maar aangezien 'de politie te dien tijde nog een korps van rustige jongens was', die er niets op tegen hadden dat 'arme kerels, ongezien, den toegang tot de wei vergemakkelijkten, door planken uit de houten schutting weg te breken', eigenden kinderen en volwassenen zich de ruimte toe. 'Op de verwilderde sprieten

84 F. Francken, 'Aan den voet van de hooge brug', in: Weerspiegeld Antwerpen, 92. gras die het weideachtige van de "wei" hadden te rechtvaardigen, probeerden zorgzame huismoeders haar linnen te bleeken. In het midden, waar de wei bultig en naakt was als een duinpan, hielden wij, bengels, ons op. We graafden er putten, bouwden er ons... in den grond, verschansingen opwerpend! ${ }^{85}$ Ondanks de politiecontroles die er op onregelmatige tijdstippen uitgevoerd werden waren de braakgronden een paradijs voor de stadskinderen. Francken beschrijft ook hoe ze speelden op het oude spoorwegemplacement. ${ }^{86}$ 'In de Ellermanstraat hadden we, buiten allerlei slag van gerij,

85 Ibidem, 93 .

86 In 2008 werd op deze locatie Park Spoor Noord geopend.

87 Francken, 'Aan den voet van de hooge brug', 94. 


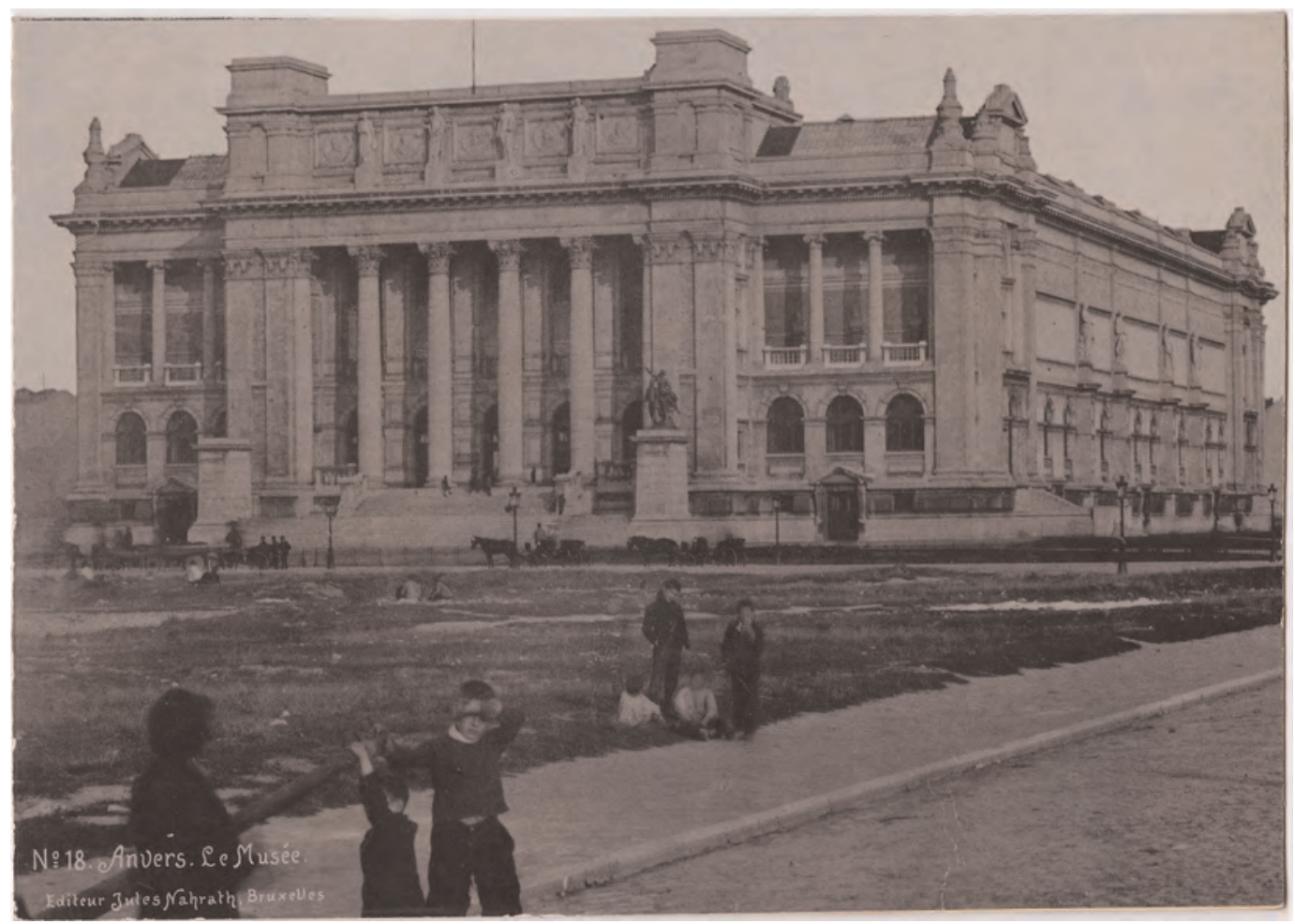

Het Koninklijk Museum voor Schone Kunsten van Antwerpen. Op de voorgrond spelende kinderen op een grasveld, voor het gebouw enkele paarden met karren, 1904

Stadsarchief Antwerpen

onder meer een kompleeten trein te onzer beschikking. ${ }^{, 87}$ De populariteit van deze omgeving voor stadskinderen blijkt uit het feit dat Van Overloop, die in het SintAndrieskwartier woonde, samen met zijn vrienden naar de wei afzakte om er te spelen. 'Het waren prachtige speelplaatsen al die "weien", [...] waar rijen spoorwagens de meest ingewikkelde spel-combinaties mogelijk maakten. ${ }^{88}$

Niet alleen in de minder gegoede, perifeer gesitueerde buurten waren er braakliggende gronden te vinden, die voor allerlei doeleinden gebruikt werden. Terwijl de 'weien' door de bewoners van de noordelijke, volkse wijken in Weerspiegeld Antwerpen vooral geassocieerd werden met

88 J. Van Overloop, 'Sint Andries', in: Weerspiegeld Antwerpen, 227. kattenkwaad, drogende was en grazende ezels en paarden, werden ze in burgerlijke middens vooral in verband gebracht met louche zaakjes. In de wijk het Zuid, die een uitgesproken burgerlijk karakter had, bleven kort na de aanleg heel wat gronden braak liggen. Een zeldzame foto van het pas gebouwde Museum voor Schone Kunsten in een verder desolate omgeving, toont verschillende groepjes kinderen die op de braakliggende gronden spelen. ${ }^{89}$

Ook in Zurenborg werden de weien beschouwd als een smet op het voorname karakter van de wijk. De wijk werd in sneltempo opgebouwd, 'uit de weiden werden de stralende straten geboren [...], elk huis werd in een handomdraai - als het schep-

89 SAA, PB \#2560. 
pen uit een pappot - neergezet', en had van bij het begin een burgerlijk karakter. ${ }^{90}$

Zurenborg zat in een kuip en alle goud en arduin van de Cogelslei konden ons, deftige mensen, niet afhelpen van wat lag aan de overzij, aan de enige verbindingsweg die wij hadden met onze 'Moederstad van Handel en Kunst'. Op de uithoek van de Antwerpse gouw lag een hol, duf, donker en smal. Net zoals in de Middelewen het schorem saamgedrumd lag buiten de poort, zo lag het hier nog voor de onze, en het bleef er jaren liggen onder de vorm van 'de Kwetterwei'. 91

Deze 'vesting van mensenlijven', zoals Schmook de omgeving noemde, was een doorn in het oog van de bewoners. Ondanks de negatieve bijklank van de braakliggende ruimtes in Zurenborg tonen negentiende-eeuwse foto's van de pas aangelegde omgeving rond de Cogels-Osylei kinderen die spelen op de nabijgelegen omwallingen en de braakgronden tussen de burgerlijke paleisjes.

Naast de braakgronden in de stad werden ook de grenzen van de stad rond de eeuwwisseling gebruikt als groene recreatieruimte. In 1906 werd het besluit genomen om de omwalling af te breken en de stad uit te breiden. Voormalig minister van openbare werken August Delbeke verwoordde de houding van de bevolking zeer treffend: 'Si d'une part, l'enceinte militaire fut, et est encore une nuisance dont il faudrait faire disparaître jusqu'au souvenir, d'autre part elle apparait, pour beaucoup, comme une couronne de verdure à laquelle il ne manque que quelques ap-

90 G. Schmook, 'Zurenborg', in Weerspiegeld Antwerpen, 180.

91 Ibidem, 181. prêts pour la rendre belle et la faire aimer'. ${ }^{92}$

De omwallingen vormden ook de fysieke en de mentale grens van de stad. Rob Van Roosbroeck beschreef de betekenis van de omwallingen uit zijn jeugd:

De hooge wallen, met hun nauwe donkere poorten, waren niet zonder bekoorlijkheid voor het stadsbeeld. Die breede gordel van blijvend groen, welke rond de stad slingerde, legde over elk gebeuren een zekere intimiteit [...]. De 'bergen', want deze weidschen naam had men aan de bescheiden wallen geschonken, waren niet alleen het hechte harnas van de stede: niet alleen het sterke schild, dat vooral aan de jeugd dit gevoel van steedsche superioriteit schonk; zij waren ook de speelplaats van de omgeving, de plaats waar tientallen van moeders in gezelligen en dikwerf zeer langen kout, door hun stoeiend kroost waren omringd. ${ }^{93}$

De omwallingen duiken in heel wat herinneringen op als een alternatieve publieke, stedelijke ruimte, en ze werden door de stadsbewoners voor allerlei doeleinden ingezet. Ook August Cleykens startte zijn wandeling door de stad in Tableaux Anversois op de plek waar stad en platteland elkaar raakten en schetste een poëtisch beeld van de omwallingen. 'Un léger rideau de brume transparente voilait le chaud soleil d'été, une brise fraîche glissait le long des remparts, c'était une de ces journées où

92 Delbeke, 'Ouverture solennelle de l'exposition du concours', 93. Terwijl de omwalling aan de ene kant een hinderlijk element was dat tot in de herinnering toe moest verdwijnen, bleek ze aan de andere kant voor velen een kroon van groen die met enkele kleine ingrepen mooi en geliefd zou zijn.

93 R. Van Roosbroeck, 'Het Zwemdokkwartier', in: Weerspiegeld Antwerpen, 332. 
l'on fuit l'ardente fournaise de la ville pour errer parmi les sentes vertes des campagnes flamandes. ${ }^{94} \mathrm{Hij}$ beschreef zijn wandeling over de omwallingen en besteedde veel aandacht aan de individuen die hij tegenkwam. Met de nodige zin voor pathetiek beschreef Cleykens een arme man - 'sa figure pâle, gravée, souffreteuse et douce, qui exhale la misère' - die zijn rechterarm miste en een mand bij zich had met enkele broden om te verkopen aan de passanten. ${ }^{95}$ Leunend tegen de dijk van de omwallingsgracht stond een oude orgelspeler, 'le miséreux tourne, tourne sans cesse'. ${ }^{96}$ Cleykens besteedde ook aandacht aan de wantoestanden die plaatsvonden op de omwallingen. Bendes jonge criminelen 'ces vagabonds, ces pâles voyous, ces rôdeurs de barrière' - zwierven rond over de omwallingen, waar ze hun hun oudere voorbeelden volgden 'à la maraude, au vol et aux mauvais coups. ${ }^{.97}$ Gerechtelijke dossiers uit het begin van de twintigste eeuw tonen bovendien aan dat de stadsmuren zich voor allerlei misdrijven leenden. ${ }^{98}$

John Broeders woonde in het noorde-

94 Cleykens, Tableaux anversois, 1: 'Een lichte waas van doorzichtige nevel omsluierde de warme zomerzon, een fris briesje gleed langs de omwalling; het was een van die dagen waarop men de gloeiende hitte van de stad ontvluchtte om rond te dwalen over de groene paadjes van het Vlaamse platteland'.

95 Ibidem, 4.

96 Ibidem, 13-14.

97 Ibidem, 14.

98 Verder onderzoek naar stadsomwallingen als plaats-delicten zou ongetwijfeld erg veel materiaal opleveren, aangezien de Antwerpse stadsomwalling in het beperkte onderzoek naar seksuele misdrijven - en meer bepaald de aanranding van minderjarigen herhaaldelijk voorkomt als plaats-delict. M. Mertens, Van pederasten, minderjarige adolescenten en onschuldige jongetjes tot het onkuise leven van 'Zwarte Fien' en 'Zwarte Jef. De gelijkslachtelijke seksuele handelingen door de ogen van de gerechtelijke instanties, 1890-1914 (onuitgegeven masterverhandeling Universiteit Antwerpen 2008). lijke deel van de stad. Hij beschreef de omgeving en de omwallingen als een schuilplaats voor 'het schuim' van de stad. $^{99}$ Zijn leeftijdsgenoot Willem Eekelers, die de omwallingen in het zuiden van de stad beschreef, hing een gelijkaardig beeld op van het gebruik van de omwalling. 'Het Half-Maantje was insgelijks de geliefkoosde plek van de "maandagvierders" die daar rendez-vous hadden, en elkaar doorgaans trakteerden op een "pikker", want de jeneverflesch was altijd van de partij. ${ }^{100}$ De jongeren mochten helpen met drank aanslepen en kregen er dan een paar centiemen voor. 'Er werd daar kaart gespeeld, gelutteerd, men vischte er, men kroop in de kastanjeboomen, men ging baden in de gracht $[\ldots]$. $\mathrm{Nu}$ en dan kwam de policie heel dat legertje opjagen. Het Half-Maantje werd dan gezuiverd. Voor een uur! Men jaagde de kerels hier weg en dààr kwamen ze alweer hun rustoord bezetten... ${ }^{101}$ De omwallingen vormden echter vooral een gedroomde speeltuin voor de kinderen die in de stad woonden, en die tot het eerste decennium van de twintigste eeuw geen speeltuinen ter beschikking hadden in de Antwerpse binnenstad. Eekelers schreef dat de omwalling zijn 'geliefkoosde speelplaats' was waar hij met zijn vrienden zwom en viste in de grachten. ${ }^{102}$ Cleykens beschreef bij zijn wandeling over de wallen de vele kinderen die hij tegenkwam. Jongens stoeiden op de omwallingen en liepen zo hard ze konden tijdens het verstoppertje of het soldaatje spelen, 'des fillettes assises font de la "dînette”, en de

99 Broeders, 'Het faboert', 158. 100 W. Eekeleers, 'Het Half-Maantje', in: Weerspiegeld Antwerpen, 194. 101 Ibidem, 195 . 102 Ibidem, 194. 
kleinsten bouwden huisjes of forten in het zand. ${ }^{103}$ Baby's, begeleid door grote zussen, moeders of kindermeisjes lagen onder parasols op dekens. ${ }^{104}$

De stadsomwalling is een stedelijke ruimte die een amalgaam aan betekenissen, belevingen, gebruiken en beelden in zich draagt. Behalve als fysieke en mentale grens van de stad diende de omwalling als speelruimte, sportterrein, schaatsbaan in de winter en roeivijver in de zomer, militair operatiegebied, flaneerboulevard, visvijver, maar ook als toevluchtsoord voor seksuele misdrijven en twijfelachtige handelstransacties, als bouwplaats voor de krotwoningen van zwervers uit de omgeving, als drinkgelegenheid, enzovoort. De omwalling vormt dan ook een perfecte illustratie van de veellagigheid van de stedelijke groenruimte. Stadsomwallingen, braakliggende gronden en restruimtes vormen samen een enorme oppervlakte aan stedelijk groen die in onderzoek tot nu toe volledig onbelicht is gebleven.

\section{Besluit}

Een oppervlakkige blik op de negentiende-eeuwse groenruimte in Antwerpen en het bijhorende beleid en gebruik wijst op een duidelijke trend: de stedelijke overheid trok almaar meer macht naar zich toe, waarbij ze zich ook wel verantwoordelijk voor haar burgers toonde, zij het vooral de eigen achterban en in mindere mate de arbeiders, en slaagde erin om zowel grote parken als kleinere plantsoenen en straatbomen in het stedelijk weefsel te integreren. Reglementen waren nodig om de bevolking te leren omgaan

103 Cleykens, Tableaux anversois, 14. 104 Ibidem, 15. met deze nieuwe structuren. Dit beeld is erg rechtlijnig en eendimensionaal, zo wordt al snel duidelijk wanneer het perspectief verruimt. Zodra men zich niet tot één type groen beperkt maar het hele gamma aan natuurlijk decorum beschouwt, tekent zich een heel wat complexere realiteit af. Wanneer men dan bovendien ook nog 'officieus' groen in de analyses betrekt - en daartoe de veelheid aan ingezette bronnensoorten verhoogt benadert men veel dichter de beleving van de negentiende-eeuwse stadsbewoner en wint de studie van stadsnatuur danig aan relevantie. Een eenduidige evolutie maakt plaats voor een gelaagd samenspel van erg verscheiden actoren, locaties, functies en motieven. Noties als 'recreatie' of zelfs 'groen' komen hieruit naar voren als erg dynamisch, met zeer verschillende invullingen. Zo is er de geleidelijke emancipatie van recreatie uit esthetiek, maar het meest uitgesproken voorbeeld is misschien wel 'grenzen'. Waren de omwallingen eeuwenlang een fysieke realiteit die de facto stad en natuur van elkaar scheidden, dan gold in vele projecten van stadsgroen het slechten van dit onderscheid als ideaal. Rond de eeuwwisseling voelden velen echter scherp aan dat een harmonieuze verzoening meer wens dan werkelijkheid was, en werd getracht opnieuw rigoureuzere grenzen te trekken, vooral om onbezoedelde natuur een kans te geven. ${ }^{105}$

De analyse van het Antwerpse stadsgroen kan bovendien nog worden doorgedreven. Er zijn immers raakpunten met op het eerste gezicht afgelegen fenomenen

105 C. Billen, 'Les métamorphoses d'un usage de la nature. Paysages et sites à l'époque de Solvay (18701914)', in: A. Despy-Meyer en D. Devreese ed., Ernest Solvay et son temps (Brussel 1997) 249-270. 
en thema's. Zo is de aanhoudende utilitaristische omgang met straatbomen rechtstreeks gelieerd aan contemporaine praktijken in sierteelt en plantkunde, terwijl het van het protest tegen het rooien van de bomen in de Leopoldslei maar een kleine stap is naar de ontluikende natuurbescherming, die in belangrijke mate uit dergelijke stedelijke fricties ontstond. Inzichten van die orde overstijgen uiteraard de Antwerpse casus. Toch zijn afzonderlijke steden het bestuderen waard, onder meer omdat uit de precieze onderhandelingsprocessen de lokale machtsverhoudingen duidelijk worden. Zo geloofde de Antwerpse elite dat zich in de omgang met openbaar groen een sociale distinctie manifesteerde, terwijl ook in de burgerij zelf onmiskenbaar neigingen tot ongeautoriseerde vormen van ontspanning bestonden én de officiële instanties voortdurend uitdaagden. Die debatten hadden bovendien ongetwijfeld nog meer diepgang dan kan worden achterhaald. Enerzijds werden ze niet altijd voluit op het publieke forum gevoerd - de teneur en precieze inhoud van besprekingen in het College, de gemeenteraad en de vele commissies is doorgaans moeilijk te achterhalen - anderzijds bestonden de onderhandelingen in ruime mate uit concrete praktijken en gedragingen. Het is dan ook tijd om de rol van gebruikers van stadsgroen naar waarde te schatten: niet enkel 'beleefden' ze wat van hogerhand werd gerealiseerd, hun verwachtingen en gebruiken hadden een niet te onderschatten impact op het beleid. In het verbinden van de fysieke stedelijke (groen)ruimte met de intense onderhandelingen tussen verschillende instanties ligt voor historici nog een belangrijke maar veelbelovende uitdaging.

\section{Over de auteurs}

Andreas Stynen (1980) promoveerde in 2010 aan de KU Leuven met een proefschrift over de relaties tussen stad en natuur in het negentiende-eeuwse België. Sindsdien is hij als onderzoeker verbonden aan het ADVN, met publicaties over onder meer populaire muziekcultuur, trans-Atlantische migratie en de internationale dimensie van nationale bewegingen. E-mail: andreas.stynen@advn.be

Bart Tritsmans (1985) is sinds 2008 verbonden aan het Centrum voor Stadsgeschiedenis van de Universiteit Antwerpen. In 2014 behaalde hij zijn doctoraat met het proefschrift Waardevolle bijkomstigheden. Stedelijk groen in beleid en beleving, Antwerpen 1859-1973. Hij is lid van het internationale onderzoeksplatform Green Space Issues and the Metropolitan City. Sinds 2010 is hij eindredacteur van het tijdschrift Stadsgeschiedenis. E-mail: bart.tritsmans @uantwerpen.be 